\title{
Code of Ethics and the Ethical Decision-making Model as a Support in Teachers' Professional Practice
}

\author{
Lukáš Stárek ${ }^{1}$ \\ Department of Special Education, Univerzita Jana Amose Komenského \\ Praha, Prague, Czech Republic
}

\begin{abstract}
Educators are confronted by specific ethical issues in their everyday work. However, awareness of these issues, the search for answers to them and their consideration, demand due diligence and time. Thus, the importance of ethics and its impact may be downplayed. An educator aims to pay attention to the development of a child/student, especially with respect to the environment or social setting itself, and the responsibility toward society itself is evident from this. The educator's responsibility should also be related to the profession itself and the social perception of the teaching profession. The aim of the research was to examine whether a school's code of ethics and the training to use an Ethical Decision-making Model could be used to support teachers in solving ethical dilemmas. The research sample consisted of teaching staff working at a primary school in Prague. The teachers work in the first stage of primary school. The selected primary school has a code of ethics as an internal regulation. In total, five interviews with teachers were conducted. Respondents agreed that the Code of Ethics and Ethical Decision-making Model are good support for their professional practice. They are primarily useful in the communication process, especially when talking to children, colleagues and parents.
\end{abstract}

Keywords: ethical code, ethical dilemma, ethics, teaching profession.

\section{Introduction}

The educator in modern society interacts with a diverse group of children/students when she/he works with or teaches extremely heterogenous groups of individuals who may be characterised by diversity that is not only cultural and linguistic in nature, but also moral. A similar situation arises in terms of moral customs, modes of behaviour and habits. A whole range of lifestyles and normative opinions converge at school and in the classroom. Consequently, educators need methods and sound knowledge in order to be able to address moral and ethical problems. According to Banks (2010), the most controversial area of ethics in helping professions is the conflict between ethical values and principles.

The teacher shares society's expectations that she/he contributes to a student's socialisation and helps her/him develop according to her/his abilities and qualities and constitutes the right to the constructive benefit for society. The student's well-being should be kept in mind during the educator's support and guidance toward a respect for cultural

1 starek.lukas@ujak.cz 
and philosophical diversity and for values such as social justice, freedom and a responsibility for democracy and the natural environment (Horster \& Oelkers, 2005). The educator should thus carry out her/his activities/tasks in the course of her/his profession with the greatest degree of knowledge and ability in the interest of the children/students, including coordination with their colleagues, and pay attention to her/his further development so as to develop the responsibility of the actors involved.

The job of educators is becoming more and more complicated and demanding. Educators have to increasingly take into account the voice and reaction of parents. Students are more diverse. School management is becoming more professional and more administratively complex. Schools and other institutions are newly defined and there are changes in legislation and key documents. Consequently, educators have to work strategically in a field that is increasingly more determined by the social and personal interests of higher positions along with cashflow/economy, legal frameworks and political power. On the other hand, it is becoming increasingly clear that the core of the teaching profession includes not only teaching but also the relationship with students and parents. Educators can barely cope with the speed of changes in the teaching profession when they have to protect its core and sometimes even fight for it, not only in schools but even in society, where the issue of teacher status is often addressed. Educators can better protect themselves and have a professional space to defend the quality of their profession. Professional ethics can play an important role in this task. For the teacher, it is not a top-down ethics but the ethics of educators that frames what governs and interconnects teaching professionals.

"A growing interest in the ethical issue of certain professions is connected to the recognition that, besides a professional qualification and the skills and habits the professional obtains as a result of specialist preparation in their future employment, certain professions still require a special personal relationship, a deep internal commitment to the selected profession" (Dorotíková, 2003, p. 30).

Investigating the ethical and moral aspects in the area of ethics of the teaching profession and in the educational process is the focus of this paper. What is and is not ethical for a teaching professional is closely connected to the tasks of pedagogy. If we start from a theoretical definition that pedagogy performs three tasks - analytical (studying/ investigating the current teaching reality); verificational (confirming the validity of certain findings) and prognostic (formulating the potential teaching aim) (Průcha et al., 2013), the educator should make an effort to ensure that students develop better by interacting with their surroundings according to their own innate qualities, needs and opinions. An illustration of the relationship between ethics and pedagogy is evident in, for example, building trust between an educator and student, the partnership of the educator and the parent and the professional collegiality not only in the teaching body.

The topic which is also connected to the ethics of the teaching profession is the educator's ability to predict the consequences of actions in relation to all actors that the educator directly or indirectly interacts with, and primarily to take responsibility for her/ his decisions. Ethics in the teaching profession thus attempts to provide proper support not only in recognizing moral problems, but also to provide instruction or direction to 
the educator who contends with these dilemmas and issues. The code of ethics of a given profession is formulated following from this definition above.

The teaching profession, just like social work or other helping professions, sees itself as a profession providing support and help, with a relationship based on trust being an integral part of it. Therefore, it is no accident that confidentiality and privacy hold an important place in the professional code. In order to be morally acceptable, it is necessary to distinguish between the following aspects that are decisive for studying ethics and its acceptability (Haterd van de et al., 2000):

- Values, norms and morality;

- Decision-making - addressing a problem;

- Professional ethics;

- Personality and attitudes.

In the Czech Republic various associations have been formed and subsequently approved, and the provisions in them are valid for all members of the association - it may include, for example, the Association of Primary School Principals; Association of Friends of Engaged Learning or the Teaching Profession Association (dissolved in 2017). However, membership is not mandatory, and an educator does not have to be involved in the activities of a given association.

Furthermore, a current problematic topic, we believe not only in the Czech Republic, is the issue of the sufficient and adequate education of the educator. According to Act 563/2004 Coll. on Teaching Staff, for the educator to be able do her/his job, she/he must have a university degree. It is thus a highly qualified profession. There is a huge proportion of teachers who keep their positions without professional qualifications. This is because before the legal provision regarding the level of teachers' qualification, the profession of teacher could be performed by people with secondary education, and the new system was still not adequate enough to force these workers to learn or move from being teacher to another teaching position that does not require a university degree, or leave school altogether. A related problem is that because of insufficient teaching staff at schools, teachers teach subjects in which they are not qualified, so there is no guarantee of education quality. For example, the reason for members of the profession to develop their own professional code could be seen as a way of professionalization, i.e. building the autonomy of the profession.

\section{Ethical Problems - Ethical Dilemmas}

Sometimes a person finds themselves in a situation, especially in their professional life, when they face the choice between two solutions. Certain problems force us to consider the situation and make a decision, which we call a dilemma. Often multiple people (groups) are involved in these dilemmas. The foundation is the awareness of one's own values, norms and interests, on which ethical behaviour is based. Ethical behaviour is viewed in the research as a behaviour that complies with a code of ethics (Stárek, 2020). 
"The Greek word problema refers to a disputable, complex situation that demands a solution. Ethical problems at least have one correct response or one possibility or a correct response. Decision-making in certain situations may be difficult, complicated or problematic, but if there is a correct solution, we cannot call it a dilemma. On the contrary, the Greek term dilema refers to an equivocal, or rather literally "dual", argument (dyo - two) in the conflicting complicated situations. Generally, we then understand dilemmas as a selection between two or more undesirable possibilities" (Mátel et al., 2010, p. 110).

Everyday practice engages with ethical issues when dilemmas often assume the forms of conflicts, questions of loyalty or making a choice. When handling these dilemmas, it is important to monitor both the social role of the educator and the relationship between an educator-child-family/parents, school.

For certain educators, dealing with ethical dilemmas may only be a matter of following firmly established rules. Other educators may view the situation as an ethical problem - an educator knows how she/he should decide, but it is complicated for her/him.

Problematic ethical topics outline the issue which an educator may encounter and encourage her/him to use all of the legal options they have - primarily to use the information and methods of the job that they use as part of the profession. It more or less involves a comprehensive procedure in handling ethical problems where it is clear that consultation with experts and colleagues is important. The basic problematic ethical topics are based on a variety of codes of ethics of teachers that we had the possibility to study. We can define them according to basic thematic areas:

- the educator and her/his surroundings;

- the educator and her/his professional 'I';

- the educator and the student;

- the educator and the parent (Dapunt, 2017).

The areas in teaching practice where ethical dilemmas and conflicts of interest may arise are extensive. We can count conflicts among employees of an organisation among them, but also conflicts between an educator and a student, conflicts between personal values and values of the educational institution, etc. The values and interests of groups of the population in a community or society have a significant influence on the issues of ethics of decision-making.

Ethical problems and dilemmas may be the consequence of conflicting situations in teaching practice. According to the experiences from the teaching practice of the author Banks (2010), we present the frequent causes of these problems:

- shortcomings of experiences and knowledge of the educator who may express her/himself in addressing challenging situations;

- unclear information on the role of the educator or of another staff member - primarily of the educator's assistant;

- untrustworthiness in the relationship among colleagues;

- ignoring the complexity of the whole situation, where the teacher is focused only on the details. 


\section{Code of ethics in the teaching profession}

A code of ethics is one of the traits of a given profession and thus determines professional values and norms (Stárek, 2015). The code determines a space and method of behaviour that simultaneously provide an anchor and direction. "A code of ethics expresses the mission of the profession. It secures the leaderships and inspiration of members, creates and maintains a professional identity, emphasises the status of the profession, serves as a benchmark for the evaluation of current practice, provides a summary of learning in the area of ethical dilemmas and protects the profession from external regulation" (Nečasová, 2008, p. 93).

The question is whether a code of ethics is a necessary document for the teaching profession or not. There are a range of opinions and speculations why such a document has not yet been drawn up and what circumstances prevent it happening. Presently, a code of ethics among teaching professionals has not been established. Teachers, as one of the oldest professions, unlike other professions (physicians, nurses, social workers, recently here even foster parents) do not have their own written code of ethics in the majority of European countries. This situation may indicate the slow process of professional self-awareness of teachers. On the other hand, it may also raise doubts whether teaching requires a written code because it has been a moral matter since its inception and has had plenty of time to have been settled throughout history (Dorotíková, 2003). Ethical dilemmas are one of the reasons why teachers need a code of ethics - to harmonize and develop a common professional code for teachers. This is the main argument why a code of ethics for the teaching profession needs to be developed / further modified, which can serve as a support for teachers in their work, in the process of addressing certain problems and dilemmas.

The code is valid for given members of a professional group. It is important for a professional group to make its professional values and norms transparent and to explain them. It thus determines the direction of professional conduct. For a professional to be able to address not only an ethical dilemma, she/he should thus know her/his own code and know how to apply it. Values and norms that are contained in the code are changeable and depend on the socio-cultural status of a given society. The creation of a code is a goal-oriented process with its main general goal being the prevention or minimisation of instances of unethical behaviour. The main reasons for supporting ethical codes are the following (Levy, 1992):

- The code safeguards the management and inspiration of its members and becomes a guide for ethical practice;

- The code supports the professional behaviour and protects the service of users from low quality of care;

- The code manages the value criteria of a given profession as a follow up to the social framework;

The code supports and creates the identity of the profession. The fundamental problem of the teaching profession is the status of the teacher in society. What determines the 
prestige of a teacher and education in today's society? "Many teachers are undervalued. They know in themselves that their career is important, but it tends to be a feeling rather than the result of an analysis. Therefore, they are not sure about it and often think that society does not appreciate them or even overlooks them as a secondary profession" (Solfronk, 2000, p. 34). However, based on studies, the significance of the teaching profession is rated very highly in comparison with other professions. A university lecturer, as well as a primary school teacher, is constantly ahead of other professions such as doctor, scientist, principal, lawyer in the research into the prestige of professions. The impression of losing the prestige of the teaching profession is based on the problems of the whole school system, referred to as the school crisis (Urbánek, 2005).

A code does not have a binding legal nature, although certain organisations may have the possibility to comment on and influence the performance of the profession of a specific professional or institution. The purpose of the code is protection through setting boundaries. Thorough adoption of a professional ethos and values has its own practical significance even for a teacher, as it will help to occasionally consider how a person regards values, without which a given profession cannot manage. From various studies - for example, Hájková (2016), who examined the issue of how the code of ethics is helpful in the teaching profession - it was determined that respondents (5 educators) agree that this document is primarily their support. It is primarily helpful in the communication process, especially when talking with children, colleagues and parents.

Starting from the importance of international information and transfer of experience, we present here the concept of the code of ethics in the USA and Switzerland. These countries were selected on the basis of the author's professional experience, not only in terms of pedagogical but also social work. For additional topics regarding the codes of ethics in individual countries, we have made use of the research of Koubková (2017), who dedicated time to comparing the code of ethics of teaching staff in selected countries. Her research looked at the codes of those countries that have a similar length of compulsory schooling and deal with the ethics of the teaching profession. Specifically, she examined the USA, France, Slovakia, Switzerland and Great Britain. It was found that codes of ethics are dedicated to the field of the rights and responsibilities of the educator for her/himself, the student, colleagues and, last but not least, the parents, and thus attempts to capture any situation that could arise because of unethical behaviour not only of the educator.

\section{USA - AAE Code of Ethics for Educators}

The school education system in the USA differs from state to state. Schools do not have uniform curricula defined by requirements according to individual states. A professional educator strives to create an environment that leads to the fulfilment of the potential of all students. The educator alone acts conscientiously according to the highest ethical standards and is of the opinion that every child is entitled to continuous education (Association of American educators, 2020).

The educator's code of ethics was developed for the American education system under the auspices of the advisory and executive committee of the Association of American 
Educators, founded in 1994, which defined the four principles of the code. The code of ethics is therefore perceived as the norm of a professional association of an educational institution.

1) Ethical behaviour towards students.

2) Ethical behaviour towards practices and performance.

3) Ethical behaviour towards a colleague.

4) Ethical behaviour toward parents and society.

(Prairat, 2009)

\section{Switzerland}

The education system in Switzerland is connected to the canton of a given area.

There is no unified given code of ethics for teaching staff in Switzerland. However, a range of associations and organisations that are dedicated, among other things, to the theme of ethics, are in place, in particular the organization of apprentices and teachers. To represent the concept of a code of ethics in Switzerland, we have used the organisation La Societé pédagogique romande, which was established in 1989.

A code of ethics is created from five subject areas, specifically:

1) The educator respects a child's fundamental rights.

2) The teacher in vocational education.

3) The educator helps to create a spirit of collegiality in the institution.

4)The teacher closely cooperates with the parents.

5) The teacher defends the school as a democratic institution.

(Prairat, 2009)

\section{Czech Republic}

In the Czech Republic, a code of ethics is not issued as a piece of legislation, based on the fact that the teaching profession does not have its own association that would protect the interests of all educators in the Czech Republic as a unified whole with its own rules of professional ethics, and whose members have a strong feeling of internal community cohesion. Yet we may seek support in international documents, for example, the Charter of Teachers, which was accepted in Paris in 1966 and which commits itself to the provisions that should be complied with by all UN member states. "Teaching organisations should draw up a code of ethics for teachers or, alternatively, a code of conduct for them; these types of codes are a significant benefit for safeguarding the prestige of the teaching profession and for fulfilling the professional obligation complying with accepted principles" (Solfronk, 2000, p. 57). There are schools in the Czech Republic that have established code as an internal regulation which is not legally enforceable, but which a teacher working at a given school is informed about and consents to following, and may be dismissed for breach of the established rules. 


\section{The Ethical Decision-making Model}

As part of professional internships and internships when I was in the Netherlands - Eindhoven, we had hearings in a special school, which also offered social services for various clients. As part of the workshop, ethical issues were addressed, which are encountered not only by pedagogical staff, but also by social workers. During this event, I first got to know this method of solving ethical issues, ethical dilemmas, and I began to pay more attention to it and do research on it. Rob Sentseis, a Dutch psychotherapist, an expert not only in relationship matters, is the creator of the Ethical Decision-making Model.

With regard to the above, it is clear that teachers are not only moral actors in society, but that they themselves address the ethical dilemmas that are part of their daily pedagogical mission.

The Ethical Decision-making Model (hereafter: EDmM) consists of several questions. Their answer should ultimately constitute an ethically responsible decision. Using this model, teaching staff will also learn to work with ethical dilemmas and, in addition, can retrospectively evaluate their decisions. This tool does not replace any code of ethics. It is a practical opportunity to approach ethical issues and especially how to deal with them effectively. The model is therefore a tool that the employee should use when working with the code of ethics.

In educational practice, ethical issues are not addressed in the necessary way. Teachers are increasingly called upon to approach them objectively and effectively. Even with the Ethical Decision-makingModel, it is not realistic to create a certain formula, full of data, which will lead us to a clear solution. The EDmMis is rather a tool that will make it easier for us to solve dilemmas without direct instructions for a specific situation. If we start from the principle that ethics is a process, not a solution in itself, questions that seek to identify the essence of a given ethical problem become the starting point. A separate point of ethical decision-making is a logical analysis of the problem in connection with the solution of the whole situation.

One of the tasks of a professional is to be able to solve and decide in situations that we can evaluate as problematic or ethically ambiguous. The EDmMor the Systematic Procedure for Solving Ethical Dilemmas (Reamer, 2013) is not a guaranteed guide to the correct outcome of the decision, but rather should help us and thus facilitate the work that brings with it many difficult situations. The personality of the teacher, her/his experience and knowledge, which we have already mentioned, also contribute to this. Experienced educators should pass on their knowledge to newcomers and try to eliminate the mistakes that these inexperienced educators can make. The importance of ethical issues may increase with the professionalisation of the profession. Ethical approaches are part of the ethical principles and values of the whole society, and every professional is faced with a choice and should be responsible for that choice.

The model (Sentse, 2010) is composed of four basic pillars, which should help in solving not only ethical dilemmas. The first point is to set out the facts themselves and identify the people who are interested in them. The following second point is the description of the regulation of behaviour and the consequences associated with it. The first two questions of this model are intended in particular to be able to describe the situation or 
dilemma as objectively as possible. The following points (III and IV) are interconnected, since they are directed towards choosing the right solution and should lead to a decision. They encourage the educator to qualify the behaviour using several criteria through a set of questions.

\section{What are the facts and who is interested in them? (cui bono)}

It is important for an educator to make a list of all the relevant facts concerning the problematic situation that needs to be addressed. The educator should attempt to produce the most objective description of the situation-dilemma possible and in the most concise wording. Emotions cannot be allowed to prevail since they would only permit the acceptance of a certain idea or perspective of a person. It is important to take a note of the people (groups) or institutions that are involved and are interested in the given problematic situation. If we succeed in meeting these set criteria, we can advance to the next step.

\section{What are the possible regulations of behaviour and what are their consequences?}

The educator's perspective should be realistic, but at the same time creative, using a conscious approach to the service user and thus creating the most angles of perspective on her/his behaviour if a given behaviour would arise. In doing so, people who are involved in the problem are empathetic to the arguments, considerations and interests. Furthermore, they need to think about what could possibly have an impact on people or an organisation/school.

\section{Testing various possibilities and their consequences}

Testing various possibilities and their consequences based on these questions:

- Is it legal?

- Are all interested parties considered?

- Is it feasible?

\section{The possibility of a decision}

If a solution is chosen, it should be accepted. A person asks different kinds of questions building on information, statements or help. One of these questions should concern the meaning and significance of existence, so they are existential questions. Central to this is, thus, the relationship between I and YOU in relation to the consideration of good and evil.

(Sentse, 2010) 


\section{Method}

The aim of the research was to examine whether the school's code of ethics and the training to use an EDmM can support teachers in solving ethical dilemmas.

\section{Data collection and analysis}

The first phase of the research was the implementation of a workshop, where teachers were first introduced to the theoretical framework of the EDmM, and then a detailed practical procedure on how to use it in their daily work, including specific practical situations they may encounter in performing their work. The workshop lasted about 180 minutes, with the participation of all respondents (five teachers) who were involved in the research.

Interviews with teachers were performed in the second phase of the research which took place four months after the workshop. The reason behind the delayed interview was the possibility of applying the acquired knowledge in practice. During this time participants also had an opportunity to consult with the workshop facilitators. As a scenario for conducting interviews, we used the prepared structure of the interview related to the topic, which stemmed from general thematic areas. The aim was to find out if teachers are aware of the code of ethics and whether they see it as helpful in their everyday work. We were also interested to find out teachers' perspectives on using the EDmM in their practice. We realised the risk that a conversation with a fixed and prepared structure of questions could be somewhat misleading. Therefore, open-ended questions were used, which we further modified according to the course of the interview with individual respondents. However, for some respondents, it was necessary to adapt the questions so that teachers were able to understand and orient themselves in the topic and its consequences.

The interview took place in an office familiar to the staff. They were offered the opportunity to be interviewed in a cafe or in a place where they would feel comfortable themselves. None of the respondents took advantage of such an offer. Meetings always took place without the presence of third parties. The creation of open contact and trust was initially induced by all respondents with general questions on the topic. Creating a friendly atmosphere, being tactful and showing a reasonable interest in the respondent's statements, helped to achieve a relaxed conversation. During the interview, we made sure that terms that the respondent did not understand were not used. The questions were formulated in a neutral way so as not to suggest the expected answer. A strategic method was chosen, where the questions started with more general problems/topics and then focused on very specific topics. The interviewer's task was to ask questions in a standardised way, with the same emphasis, in all interviews. All five interviews took place without any sudden or embarrassing situations that could undermine the trust between the respondent and the interviewer. All five teachers showed maximum helpfulness, but also interest in the topic. The average duration of the interview was about 45 minutes.

Conversations from the working meeting and the interviews were recorded on a digital voice recorder, with informed consent by the participants. The findings from the 
workshop were more of an observational nature and were introduced into the evaluation during the interview. The data were systematically coded. An inductive approach to coding was used. At the later stage, codes were grouped into categories based on their similarity.

\section{Participants}

A total of five semi-structured interviews took place. The selection of respondents is linked to the long-term cooperation between the university (home workplace of the author of the text) and the school. The research sample was thus made up of teaching staff working at one primary school in Prague. The teachers work at the first stage of primary school and are all class teachers (ISCED-1). An overview of the sociodemographic characteristic of the participants is presented in Table 1.

The selected primary school has a code of ethics as an internal regulation, which is focused on basic areas - the relationship between teacher and students, teacher and parents, teacher and school... At the primary school in question, the code of ethics as an internal document is adopted once a year. The school is responsible for the code of ethics and adjusts it according to the practical recommendations of teachers, inspections, and advice from parents and students.

Table 1

Overview of the sociodemographic background of the participants

\begin{tabular}{lllll}
\hline Respondent & Gender & Age & Years of teaching experience & Level of education \\
\hline respondent 1 & woman & 58 & 31 years & university \\
respondent 2 & woman & 33 & 3 years & university \\
respondent 3 & man & 62 & 41 years & secondary school \\
respondent 4 & man & 34 & 8 years & university \\
respondent 5 & woman & 48 & 22 years & university \\
\hline
\end{tabular}

\section{Findings}

\section{Teachers' perceptions of the code of ethics and its usefulness in resolving ethical dilemmas}

Teachers' awareness of the code of ethics is clear and obvious. The primary reason is the fact that the research took place at a school that has a code of ethics as an internal document. Respondents were able to speak on the topic of the code without major problems, thanks to their own experience with this document. Given that teachers are constantly acquainted with the code of ethics and information is updated every year, it 
is clear that they perceive the code of ethics as part of the profession. With regard to the internal document, it is also clear that the teachers know about its existence. Areas that educators have addressed or believe that they could address within the code of ethics are primarily the standards of education of all participants in the educational process; ways of dealing with children and parents; respect for the differing views of others; defining the relationship between colleagues; tolerance for students' behaviour and needs, and setting an example by one's own actions. All the educators we interviewed said that the code of ethics for their profession should be a standard that includes ways of behaving and dealing with school clients.

Individual points of the code of ethics guide the conduct and behaviour of each individual in the body of teachers, and at the same time the code ensures the performance of a school as a whole, with no individual's behaviour singled out. It encourages teachers in their job performance, leads them to cooperation with colleagues, makes them consider their behaviour and, at the same time, imparts a responsibility to perceive people (colleagues) around them and react to their performance. Every member of the teaching staff has the right to express disagreement with the attitude of another, but she/he should accept criticism and recommendations from others. This idea was expressed by all respondents.

Educators who use the code at school stated that they could no longer imagine their work without the document. It is advantageous for them to be able to look at the rules and constantly keep them in mind. They can refer to the code of ethics and do not have to hesitate in their behaviour. They have clear rules, and if they deviate from them, they are notified in good time. Some of them find it unbelievable that not every school has this document, because it is a great benefit for them personally.

All educators agree that the code of ethics is their main support, which supports the importance of existence of a document that addresses ethical issues in relation to their profession. It is especially helpful in the process of communication, when dealing with children, colleagues or parents.

\section{Teachers' perceptions of the usefulness of the ethical decision-making model in resolving ethical dilemmas}

The primary situations in which educators used the EDmM were in the relationship between teacher and students, and teacher and colleagues. The overview of data is presented in Table 2. 


\section{Table 2}

\section{Systematization of data on teachers' use of EDmM}

\begin{tabular}{|c|c|c|c|c|}
\hline Respondent & Area of work & Problem & Action taken & $\begin{array}{l}\text { How was the EDmM } \\
\text { helpful }\end{array}$ \\
\hline Respondent 1 & $\begin{array}{l}\text { Cooperation with } \\
\text { parents. Link to } \\
\text { social activities in } \\
\text { the area and lei- } \\
\text { sure activities of the } \\
\text { school. }\end{array}$ & $\begin{array}{l}\text { Suspicion on child } \\
\text { neglect. }\end{array}$ & $\begin{array}{l}\text { Communication with parents. } \\
\text { Setting rules in free time. } \\
\text { Provision of social services - } \\
\text { leisure club. } \\
\text { The respondent's own reflec- } \\
\text { tion on her free time. }\end{array}$ & $\begin{array}{l}\text { Systematic thinking } \\
\text { about the situation } \\
\text { not only in relation } \\
\text { to the child, but also } \\
\text { to oneself. }\end{array}$ \\
\hline Respondent $2^{*}$ & $\begin{array}{l}\text { Frequency of com- } \\
\text { munication with } \\
\text { socially disadvan- } \\
\text { taged parents. }\end{array}$ & $\begin{array}{l}\text { Low frequency of } \\
\text { contact with par- } \\
\text { ents of children at } \\
\text { risk. Parents do not } \\
\text { respond to an in- } \\
\text { vitation to school. } \\
\text { The teacher leaves } \\
\text { the initiative to the } \\
\text { parents. }\end{array}$ & $\begin{array}{l}\text { A response is required for each } \\
\text { contact by a specific date. } \\
\text { There is no response contact } \\
\text { addressed by the school man- } \\
\text { agement and subsequently } \\
\text { the office - the social depart- } \\
\text { ment. measures taken by the } \\
\text { school - professional sessions } \\
\text { required for teachers with } \\
\text { short experience. }\end{array}$ & $\begin{array}{l}\text { Gaining control over } \\
\text { the situation and } \\
\text { not being afraid to } \\
\text { solve problems - to } \\
\text { share problems with } \\
\text { school manage- } \\
\text { ment or colleagues. }\end{array}$ \\
\hline Respondent $3^{*}$ & Personal settings. & $\begin{array}{l}\text { Reluctance/help- } \\
\text { fulness to deal } \\
\text { openly with some } \\
\text { situations related } \\
\text { to the topic of the } \\
\text { code of ethics and } \\
\text { EDmM. }\end{array}$ & $\begin{array}{l}\text { Length of practice and life } \\
\text { experience are not always a } \\
\text { guarantee of an open attitude. }\end{array}$ & $\begin{array}{l}\text { Finding out that mo- } \\
\text { ments / situations } \\
\text { that have been in- } \\
\text { ternally addressed } \\
\text { are addressed by } \\
\text { colleagues publicly } \\
\text { and openly. }\end{array}$ \\
\hline Respondent 4 & $\begin{array}{l}\text { Relationship with } \\
\text { colleague. } \\
\text { Student's vulgar } \\
\text { behaviour. }\end{array}$ & $\begin{array}{l}\text { Student's vulgar } \\
\text { behaviour - vul- } \\
\text { gar words, verbal } \\
\text { aggression, in- } \\
\text { adequate anger, } \\
\text { with which the } \\
\text { respondent dealt } \\
\text { with the child's } \\
\text { class teacher. }\end{array}$ & $\begin{array}{l}\text { Focus on area of interest of the } \\
\text { student. Monitoring situations } \\
\text { that cause student behaviour. } \\
\text { Evaluation within the profes- } \\
\text { sional team - school psycholo- } \\
\text { gist and other teachers who } \\
\text { interact with the student. }\end{array}$ & $\begin{array}{l}\text { Basis for systematic } \\
\text { action and coopera- } \\
\text { tion of members of } \\
\text { the teaching staff. }\end{array}$ \\
\hline Respondent 5 & $\begin{array}{l}\text { Relationship with } \\
\text { colleague. }\end{array}$ & $\begin{array}{l}\text { Lack of sympathy, } \\
\text { conflicts. }\end{array}$ & $\begin{array}{l}\text { Choosing a model of behav- } \\
\text { iour for this colleague. The } \\
\text { school management also aims } \\
\text { at professional behaviour with- } \\
\text { in the solution of this area in } \\
\text { the code of ethics. }\end{array}$ & $\begin{array}{l}\text { Basis for systematic } \\
\text { action. } \\
\text { Awareness that pro- } \\
\text { fessionalism and } \\
\text { ethics are related - } \\
\text { without ethics, one } \\
\text { would not be a pro- } \\
\text { fessional. }\end{array}$ \\
\hline
\end{tabular}

Note. With regard to the scope of the text, the reactions / situations mentioned by respondents 2 and 3 are not elaborated in the text. 
In the specific situations mentioned by the respondents - the situation in the field of behaviour and attitudes of students, teachers and parents, the respondents focused more on the issue of education about the social values that children learn from their parents or from their natural social environment. Within these considerations, four respondents do not consider the use of the EDmM to be important or beneficial. Respondent 1 used the EDmM when dealing with suspicions of child neglect- when one of the children went to school without a snack and inadequately dressed. Poor communication with parents and no response to requests for a change of attitude meant that school management had to turn to the authorities. There was a discussion about the responsibility of parents in the care of the child. The EDmM helped the teacher to systematically think about the situation so that she could rationally handle the situation from her position. Actions that were undertaken resulted in rising awareness of the educational process and securing maximum support in the social field - expanding and consolidating habits so that the child could function not only at school but also at home.

Another area in which Respondents 4 and 5 used the EDmM was in relation to their colleagues. Respondent 4 focused a lot on the area of interests of the participants in solving the student's vulgar behavior - vulgar words, verbal aggression, inappropriate anger, with which he dealt with the child's class teacher. Here the result was similar as in the case of the previous respondent - i.e. the EDmM provided the basis for systematic action. Respondent 5 resolved interpersonal conflicts with a colleague from the second stage of primary school thanks to the EDmM. According to the respondent, there was a mutual lack of sympathy among teachers, thus their conversation always resulted in an open conflict, where the given area of the topic was secondary. It is interesting that the respondent had this rational view and was able to evaluate the situation in this way. The EDmM helped as another tool for choosing a model of behaviour for this colleague. The respondent approached this situation with regard to the code of ethics, when he attacked the management to begin to address not only the professionalism of the teacher, but also his professionalism, where behaviour and respect have their place.

From the interview with Respondent 1, it is based on the reality or observation that there are very fragile boundaries between the teacher and the student, which can be disturbed by any "little thing", which then becomes an ethical dilemma. In this situation, it was inadequate tense behaviour of the child who wanted to be with the respondent in his free time - for example, on the weekend, also conditioned by the fact that the respondent lives on the same street as the child and his family. The model helps respondents to think more deeply about the whole situation - it is her moral duty to fill the child's free time and ensure a suitable social environment for the child. The question also arose as to how the respondent herself should deal with her free time when she no longer lives with her children and has no grandchildren.

The importance of knowledge and practical application of the code and EDmM therefore seems necessary in order to prevent certain ethical dilemmas. Moral contradictions can appear in everyday activities and situations that make up the workload of the teacher. The element of moral conflict is evident, but the personal setting of teachers is no longer so clear. The key area that was challenging and not always met by all respondents 
who used the EDmM was the essence of awareness / use of the offer of "all" possible solutions. The respondents interviewed confirm that information sharing is essential for good teaching practice and does matter in this regard.

\section{Conclusion}

Experiences and evaluations of the usefulness of support methods vary from teacher to teacher. In each profession, the personality of the individual and her/his attitude to moral values and morality are intertwined. It follows that the moral duty of a teacher is to remain a constantly learning professional, to participate in education and training in recognised training centres, to follow professional literature, consult with colleagues, learn from past cases, share knowledge and work on the ability to form moral judgment. Thinking and discussing ethical issues in the teaching profession does not come by itself. In addition to time, helpfulness, empathy and a certain degree of discipline are necessary.

One of the main ideas, which is based on the general level of codes of ethics, is the mutual support and opportunity for help that we can expect from colleagues. The first step is the positive relationships in the workplace, which we primarily address by respecting the knowledge and experience not only of our colleagues, but also of other professionals.

Although we do not want to assess the ethical code of the organisation or the $E D m M$, a positive reaction from employees is evident. The effective applicability of the code of ethics and the EDmM in relation to the daily performance of the profession therefore remains a problematic area. Often teachers are not aware of the depth of the problem posed by an ethical dilemma. In their daily activities, they do not realize the idea of a code of ethics. They do not address ethical issues. The moral orientation of teachers is in a key position in the field of origin and subsequent processing of the ethical dilemma. This was confirmed by all respondents - thanks to the code of ethics and the EDmM, they started working with awareness and solving ethical dilemmas. We point out the need for a deeper understanding in the area of ethics itself, while constantly supporting the interest in the relationship with the child, the student's parents and also with the organisation/school.

Research findings are linked to the very basis of the professionalism of teachers or other helping professions. If we support the idea of professionalization, then ethics and professional ethics are an integral part of this process. Research points to the realistic/ practical use of codes of ethics in particular. The question therefore relates to the form, setting and content of these documents, which are currently an integral part of the profession, but are very superficially conceived. The resulting recommendation is to take into account the professional profile of the staff, who are not only teachers, but are becoming experts in the field with regard to the focus of assistance and support of a particular target group (children / students, children / students with disabilities) or certain areas (education, social work, etc.). It is therefore necessary to modify and specify the area of ethics with regard to the professional orientation of the employee or specialisation in the target group. Subsequently, the worker can better identify possible pitfalls not only in relation to the work as such, but also to himself. 
At the level of teacher training, it is therefore also necessary to assume that the solution of ethical issues and approaches is a deficit and that it is not implemented in vocational education. However, ethically trained educators are essential for students to be able to learn ethically (Dapunt, 2017).

Ethics are also related to how teachers can gradually grow, what is truly desirable and worth monitoring. Engaging in the ethics of one's profession means constantly looking for what is really "good" in order to achieve an even more responsible practice.

The ethics of professional life should correspond to the ethics of overall life. It is necessary to value the personal qualities and moral position of each teacher. In addition to the codified rules and ethical principles that must be observed, it is important and indispensable for the teaching profession that a worker has a high level of moral and personal values. Ethics are an integral part of the teaching profession.

\section{References}

Asociaci ředitelů základních škol (2020, February, 22). Hlavní cíle asociace. Retrieved from http://www. asociacezs.cz/

Association of American Educators (2020, January, 10). Code of Ethics for Educators. Retrieved from https://www.aaeteachers.org/

Banks, S. (2010). Interprofessional ethics: A developing field? Notes from the Ethics \& Social Welfare Conference, Ethics and Social Welfare, 4(3), 80-94.

Dapunt, V. (2017). Zur Notwendigkeit ethischer Bildung der Lehrerinnen und Lehrer (diploma thesis). Retrieved from https://othes.univie.ac.at/45360/1/47393.pdf

Dorotíková, S. (2003). Profesní etika učitelství. Praha: Univerzita Karlova, Pedagogická fakulta.

Hájková, H. (2016). Etický kodex učitele. Praha: Diplomová práce, Jihočeská univerzita v Českých Budějovicích, Pedagogická fakulta.

Haterdt van de, J. et al. (2000). Beroepsprofiel van helpenden en verzorgenden. Utrecht: Elsevier Gezondheidszorg/LCVV.

Horster, D., \& Oelkers, N. (2005). Pädagogik und Ethik. Wiesbaden: Springer VS.

Koubková, G. (2017). Etické kodexy v učitelské profesi. Brno: Bakalářská práce, Mendelova univerzita v Brně, obor studia: Institut celoživotního vzdělávání.

Levy, S. Ch. (1992). Social Work Ethics on the Line. London: The Hawort Press.

Mátel, A. et al. (2010). Aplikovaná etika v sociální práci. Brno: Institut mezioborových studií Brno.

Nečasová, M. (2008). Profesionalismus a etické kodexy v sociální práci. In O.Fischer, \& R. Milfait (Eds.), Etika pro sociální práci, (pp. 72-94). Praha: JABOK.

Prairat, E. (2009). De la délontologie enseignante: valeurs et bonnes pratiques. Paris: Presses universitaires de France.

Průcha, J., Walterová, E., \& Mareš, J. (2013). Pedagogický slovník. Praha: Portál.

Reamer, G. F. (2013). Social Work Values and Ethics. New York: Columbia University Press.

Sentse, R. (2010). Levensbeschouwing \& Ethiek. Retreived from http://pt.slideshare.net/RobSentseBc/ ethisch-besluitvormingsmodel; 
Solfronk, J. (2000). Učitelství jako profese. Liberec: Technická univerzita.

Stárek, L. (2015). Etický kodex jako profesní výzva v osobní asistenci - I. část. Listy sociální práce, 8(23), 18-19.

Stárek, L. (2020). Etický model rozhodování se jako profesní nástroj. Studia Scientifica Facultatis Paedagogicae Universitas Catholica Ružomberok, 19(3), 42-57.

Urbánek, P. (2005). Vybrané problémy učitelské profese: aktuální analýza. Liberec: Technická univerzita v Liberci, Fakulta pedagogická.

\title{
Legal sources:
}

Act No. 563/2004 Coll., On pedagogical staff and on the amendment of certain laws (Education Act). In: Collection of laws of the Czech Republic.

\section{Кодекс етике и етички модел доношења одлука као подршка у професионалној пракси наставника}

\author{
Лукаш Старек \\ Департман за специјално образовање, \\ Универзитет Јан Амос Коменски Праг, Праг, Чешка
}

\begin{abstract}
Айсйракй

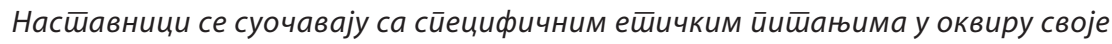
свакояневне йраксе. Међушиим, развој свесӣи о овим ӣишањима, ӣош̄раїа за

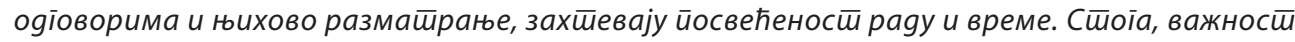

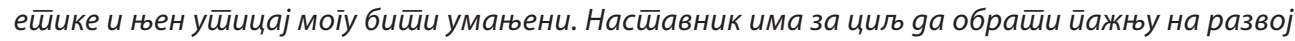
gешеиейа/ученика, йосебно уйоїлеgу околине или са̂мої gрушйвеної окружења, и из йоїа се може

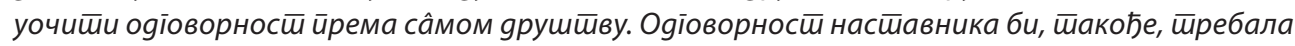
gа се gовоgи увезу са њеїовом йрофесијом и друшишвеном йериейцијом насйавничке йрофесије.

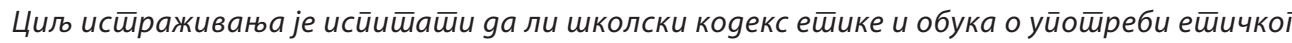

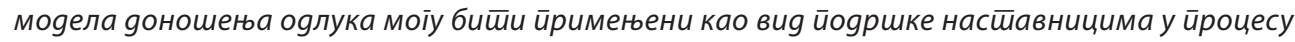
решавања ешиччких дилема. Узорак исшираживања су чинили насйавници који раgе у јеgној основној школи у Праїу. Насйавници раgе у нижим разреgима основне школе. Оgабрана

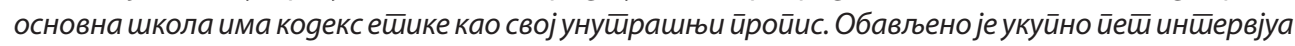

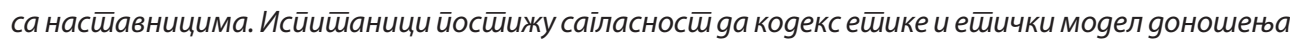
о олука моїу бишии значајна ӣоgршка у њиховој ӣрофесионалној йракси. Такође, йоказало се gа

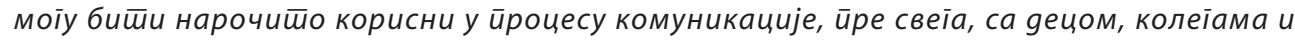
роgишељима.
\end{abstract}

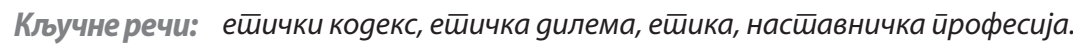




\title{
Кодекс этики и этическая модель принятия решений как опора в профессиональной практике учителей
}

\author{
Лукаш Старек \\ Департамент специального образования, Университет имени Яна Амоса Коменского, \\ Прага, Чешская Республика
}

\begin{abstract}
Резюме Всвоей повседневной практике учителя сталкиваются с определенными этическими требуют посвящения работе и времени. Следовательно, важность этики и ее влияние могут быть уменьшены. Учитель стремится обратить внимание на развитие ребенка / ученика, особенно с точки зрения окружающей или самой социальной среды, и в этом можно увидеть ответственность перед самим обществом. Ответственность учителя также должна быть связана с его профессией и общественным восприятием профессии учителя. Цель исследования - изучить, можно ли применять школьный этический кодекс и подготовку к использованию этической модели принятия решений в качестве формы поддержки учителям в процессе решения этических дилемм. В исследовании приняли участие учителя, работающие в младших классах в одной начальной школе в Праге. Выбранная начальная школа имеет этический кодекс в качестве внутреннего регламента. Всего было проведено пять интервью с учителями. Анкетированные учителя согласны с тем, что этический кодекс и этическая модель принятия решений могут оказать существенную поддержку в их профессиональной деятельности. Также было показано, что они могут быть особенно полезны в прочессе общения, прежде всего, с детьми, коллегами и родителями.
\end{abstract}

Ключевые слова: этический кодекс, этическая дилемма, этика, педагогическая профессия. 